\title{
Release of ammonium and urea from dissolved organic nitrogen in aquatic ecosystems
}

\author{
Tom Berman $^{1, *}$, Christian Béchemin ${ }^{2}$, Serge Y. Maestrini ${ }^{2}$ \\ ${ }^{1}$ Israel Oceanographic and Limnological Research, Yigal Allon Kinneret Limnological Laboratory, PO Box 345 , \\ Tiberias 14105, Israel \\ ${ }^{2}$ CREMA-L'Houmeau (CNRS-IFREMER), BP 5, F-17137 L'Houmeau, France
}

\begin{abstract}
The potential for release of ammonium $\left(\mathrm{NH}_{4}{ }^{+}\right)$and/or urea from the pool of dissolved organic nitrogen (DON) was examined in samples taken from Lake Kinneret (Israel), the River Charente estuary and coastal water near lle de Ré (French Atlantic coast). After prefiltration through 1.0 or $1.2 \mu \mathrm{m}$ membranes to remove most of the microbiota with the exception of bacteria, water samples with or without supplements $(40 \mu \mathrm{M})$ of various organic nitrogen compounds (arginine, glucosamine, guanine, hypoxanthine, lysine, ornithine or thymine) were incubated at in situ temperatures, in the dark, for 7 to $14 \mathrm{~d}$. Concentrations of $\mathrm{NH}_{4}{ }^{+}$and urea were monitored during the incubation period. Increases of $\mathrm{NH}_{4}{ }^{+}$with time were observed in 8 out of 12 experiments with unsupplemented lake samples, and in a single trial with coastal water, but not with Charente estuary water. In some experiments, increases of urea concentrations were also observed. The addition of organic nitrogen compounds almost always led to $\mathrm{NH}_{4}{ }^{+}$increases in samples from all locations; guanine, hypoxanthine, arginine and, in the case of Charente water, glucosamine gave rise to urea. The addition of nitrification inhibitors $(40 \mu \mathrm{M})$ at the start of some experiments gave inconsistent results, but in some cases appeared to increase the concentrations of $\mathrm{NH}_{4}{ }^{+}$with time. Taken together, the results of these experiments clearly indicate the potential in natural waters for degradation of DON pool constituents by indigenous bacteria and/or free dissolved enzymes to $\mathrm{NH}_{4}{ }^{+}$or urea; these in turn can be effectively exploited by the ambient microbiota. The breakdown of DON with the concomitant release of readily available compounds such as $\mathrm{NH}_{4}{ }^{+}$or urea could be an important process in the nitrogen nutrition of phytoplankton and bacteria.
\end{abstract}

KEY WORDS: DON $\cdot$ Decomposition $\cdot \mathrm{NH}_{4}{ }^{+} \cdot$ Urea $\cdot$ Bacteria $\cdot$ Lake $\cdot$ Estuary

\section{INTRODUCTION}

Recently there has been a revival of interest in the role of dissolved organic nitrogen (DON) in aquatic ecosystems (Antia et al. 1991, Carlsson et al. 1993, Bronk et al. 1994, Ogata et al. 1996, Berg et al. 1997) and some current research has been prompted by the hypothesis that organic terrigenous compounds might favour blooms of toxic algal species (Granéli et al. 1985, Granéli \& Moreira 1990). Frequently the concentrations of DON in near-surface pelagic waters, both in the oceans and in lakes, are considerably greater than the dissolved inorganic fixed nitrogen pool (DIN) of

\footnotetext{
•E-mail: tberman@inter.net.il
}

nitrate, nitrite and ammonium $\left(\mathrm{NO}_{3}{ }^{-}, \mathrm{NO}_{2}{ }^{-}\right.$and $\left.\mathrm{NH}_{4}{ }^{+}\right)$ which is generally considered to supply most of the nitrogen $(N)$ utilised by planktonic microbiota (Jackson \& Williams 1985, Libby \& Wheeler 1997). Although it has long been assumed that there is a flux of $\mathrm{N}$ from the DON pool to microorganisms in most aquatic systems, there have been few experimental studies of this process in natural environments.

Components of the DON pool may undergo extensive transformations and cycling in the euphotic zone (Palenik et al. 1988/1989, Pantoja et al. 1997) and thus provide a significant source of nitrogen for the resident microbiota (Berman 1997). Some DON compounds can be taken up directly by bacteria (Flynn \& Butler 1986, Paul et al. 1986, Simon \& Rosenstock 1992) or by phytoplankton (Antia et al. 1975, Kapp et 
al. 1975, Neilson \& Larson 1980, Oliveira \& Huynh 1989, Berman et al. 1991). Field research also proved that urea is an important potential nitrogen source for phytoplankton in several coastal waters (McCarthy 1972, Price \& Harrison 1988, Tamminen \& Irmisch 1996), and dissolved free amino acids have been reported to sustain a significant part of algal growth in the Chesapeake Bay (Glibert et al. 1991). Moreover, Palenik et al. (1988/1989) have shown that some phytoplankton are able to use various forms of DON without initial transport into the cell, by using cellsurface enzymes to degrade these forms of nitrogen to $\mathrm{NH}_{4}{ }^{+}$. Nevertheless, probably a more important pathway for DON utilisation by phytoplankton in nature is the release of $\mathrm{NH}_{4}^{+}$from DON compounds as a result of bacterially mediated, enzymatic breakdown and deamination (Pantoja et al. 1997). Subsequently the released $\mathrm{NH}_{4}{ }^{+}$would be available for bacterial and phytoplankton uptake or might be transformed to nitrate via nitrifying bacteria.

Here we describe a series of experiments in which we examined the release of $\mathrm{NH}_{4}{ }^{+}$and urea from natural DON or from added DON substrates in the nearsurface waters of Lake Kinneret, Israel, in the Charente estuary and in coastal waters near lle de Ré, French Atlantic. The results of these experiments clearly indicate the potential of components of the DON pool to provide available nitrogen for phytoplankton and bacteria.

\section{SITE LOCATIONS, MATERIALS AND METHODS}

Twelve freshwater samples were taken from August 1996 to September 1997 in Lake Kinneret, Israel $\left(32^{\circ}\right.$ $53.4^{\prime} \mathrm{N}, 35^{\circ} 38.5^{\prime} \mathrm{W}$ ), from 1 to $3 \mathrm{~m}$ depth, at a $40 \mathrm{~m}$ deep central station (Table 1). Estuarine water (4 experiments) was sampled from July to August 1997 in the Charente River mouth $\left(45^{\circ} 57.4^{\prime} \mathrm{N}, 1^{\circ} 03.2^{\prime} \mathrm{W}\right)$, France. Atlantic coastal marine water (1 experiment) was collected nearby $\left(46^{\circ} 16.5^{\prime} \mathrm{N}, 1^{\circ} 23.5^{\prime} \mathrm{W}\right)$.

In order to remove almost all of the phytoplankton, lake samples were filtered through pre-rinsed $1 \mu \mathrm{m}$ pore Nuclepore filters; Charente and coastal water was filtered using a Milipore $1.2 \mu \mathrm{m}$ Opticap Filter unit. Portions of 500 to $1200 \mathrm{ml}$ of filtered water were distributed into triplicate, clear polycarbonate bottles or Erlenmeyer flasks which were then incubated in the dark for 7 to $15 \mathrm{~d}$, at ambient lake, estuarine or coastal water temperatures: 18 to $25^{\circ} \mathrm{C}, 18^{\circ} \mathrm{C}$ and $18^{\circ} \mathrm{C}$, respectively. During the incubations, the concentrations of ammonium, urea and, in some experiments, nitrate plus nitrite were measured initially and at 24 or $48 \mathrm{~h}$ intervals. In some cases, initial and final concentrations of DON were also determined.
In order to examine the potential for the release of $\mathrm{NH}_{4}{ }^{+}$and urea from various DON compounds that might be of importance in the DON pool, parallel water samples supplemented with hypoxanthine, guanine, thymine, glucosamine, arginine, lysine, ornithine or leucine (all at concentrations of $40 \mu \mathrm{M}$ of $\mathrm{N}$ ) were incubated in addition to the samples with unamended, 1 or $1.2 \mu \mathrm{m}$ filtered, water (i.e containing only ambient DON). These compounds were chosen as representative of some of the more labile fractions derived from major biological cell constituents that might be expected to be present in the DON pool. Contamination of $\mathrm{NH}_{4}{ }^{+}$or urea in these compounds was never greater than $0.5 \%$.

Several experiments were made to determine the extent to which $\mathrm{NH}_{4}{ }^{+}$released from DON might be transformed to $\mathrm{NO}_{3}{ }^{-}$as a result of bacterially mediated nitrification. The nitrification inhibitors tested were 2chloro-6-(trichloromethyl) pyridine [N-serve], cyanoguanidine, thiourea, picollinic acid and allyl-thiourea. Parallel samples of lake or estuarine water with or without nitrification inhibitors $(40 \mu \mathrm{M})$ were incubated as described above and changes in $\mathrm{NH}_{4}{ }^{+}$, urea and $\mathrm{NO}_{3}{ }^{-}$concentrations were measured over periods of 7 to $15 \mathrm{~d}$.

The analytical methods used to determine $\mathrm{N}$ concentrations were as follows: DON (Nydahl 1978), ammonium (Solarzano 1969), nitrate (Anonymous 1992) and urea (McCarthy 1970). The latter method was modified by using a dialysed preparation of jack bean urease Type IV (Sigma). The results of all analyses were based on averages of 3 to 5 replicate samples. Note that all concentrations of the nitrogen compounds are given as $\mu \mathrm{MN}$.

Table 1. Lake Kinneret, Israel: ambient concentrations of nitrogen fractions and maximum increases in $\mathrm{NH}_{4}{ }^{+}$and urea observed in experiments. All experiments with $1.0 \mu \mathrm{m}$ filtered lake water; all concentrations are $\mu \mathrm{M}$ of nitrogen; nm: not measured; (-) no increase in $\mathrm{NH}_{4}{ }^{+}$

\begin{tabular}{|lcrcccc|}
\hline Date & $\mathrm{NH}_{4}$ & $\mathrm{NO}_{3}$ & Urea & DON & $\Delta \mathrm{NH}_{4}$ & $\Delta$ urea \\
\hline 26 Aug 96 & 0.9 & $<0.1$ & $\mathrm{~nm}$ & 15.0 & $9.6^{\mathrm{d}}$ & $\mathrm{nm}$ \\
27 Oct 96 & 1.4 & 0.7 & $\mathrm{~nm}$ & 16.7 & 3.7 & $\mathrm{~nm}$ \\
1 Dec 96 & 8.7 & 1.4 & $\mathrm{~nm}$ & 18.0 & 1.4 & $\mathrm{~nm}$ \\
20 Jan 97 & 4.0 & 5.1 & 1.0 & 16.6 & 4.4 & 0.6 \\
24 Feb 97 & 3.6 & 9.0 & $\mathrm{~nm}$ & 21.9 & 1.8 & $\mathrm{~nm}$ \\
10 Mar 97 & 2.8 & 21.6 & 0.9 & $\mathrm{~nm}$ & - & 1.6 \\
5 May 97 & 1.3 & 25.6 & 0.5 & 13.0 & - & 0.4 \\
26 May 97 & 0.6 & 2.5 & 1.0 & 15.7 & 2.8 & 0.9 \\
23 Jun 97 & 3.6 & 1.0 & 1.0 & 21.3 & - & 1.4 \\
13 Jul 97 & 0.3 & 0.2 & 0.1 & 19.9 & 2.1 & 1.1 \\
10 Aug 97 & 0.9 & $<1.0$ & 5.1 & 20.1 & 3.4 & 3.7 \\
7 Sep 97 & 0.2 & 0.5 & 0.4 & 23.5 & 4.7 & 0.1 \\
anly with addition of nitrification inhibitor & & \\
a Onj & & & \\
\hline
\end{tabular}




\section{RESULTS}

\section{Release of $\mathrm{NH}_{4}{ }^{+}$and urea from ambient DON}

In 9 experiments made with Lake Kinneret water from August 1996 to September 1997, there were clearly detectable increases in $\mathrm{NH}_{4}{ }^{+}$concentrations during 7 to $14 \mathrm{~d}$ incubations in pre-filtered samples to which no additions of organic nitrogen compounds were made (Table 1, Fig. 1). The patterns of $\mathrm{NH}_{4}^{+}$ increase varied; in some cases, there was a marked drop during the last days of incubation (e.g. Fig. 1A), in other experiments, $\mathrm{NH}_{4}{ }^{+}$concentrations increased to a plateau (Fig. 1B, C, D). Often there was an initial 2 to $3 \mathrm{~d}$ lag prior to the increase of $\mathrm{NH}_{4}{ }^{+}$concentrations (Fig. 1B, C, D, E). By contrast, no increase in $\mathrm{NH}_{4}^{+}$concentrations from ambient DON during incubations was observed in 3 experiments made in March, early May and June 1997

Ambient concentrations of $\mathrm{NH}_{4}{ }^{+}, \mathrm{NO}_{3}{ }^{-}$and DON in the lake ranged from 0.9 to $8.7,<0.1$ to 1.4 and 15.0 to $18.0 \mu \mathrm{M}$, respectively, during the period from August
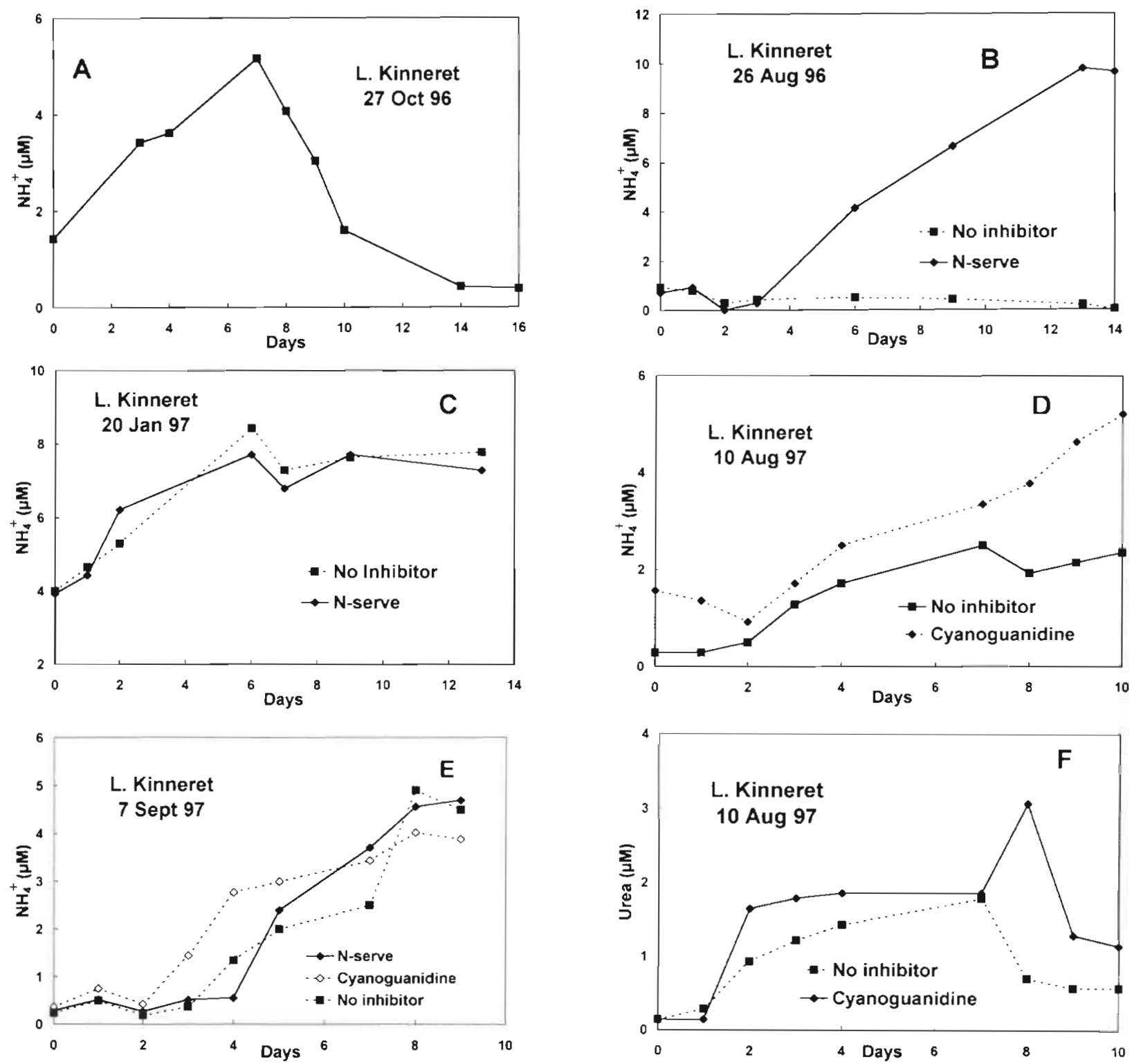

Fig. 1. Changes in concentration $(\mu \mathrm{M})$ of $\mathrm{NH}_{4}{ }^{+}$during incubation of Lake Kinneret water prefiltered through $1 \mu \mathrm{m}$ pore polycarbonate membranes. Water taken from a central lake station at dates indicated. (B, C, D, E) $\mathrm{NH}_{4}{ }^{+}$concentrations in samples with added nitrification inhibitors, $\mathrm{N}$-serve or cyanoguanidine $(40 \mu \mathrm{M})$. (F) Changes in concentration (as $\mu \mathrm{M} N$ ) of urea with and without addition of cyanoguanidine 
through late December 1996. With winter flood inputs from the River Jordan and lake overturn, the concentrations of $\mathrm{NH}_{4}{ }^{+}, \mathrm{NO}_{3}{ }^{-}$and DON ranged from 1.3 to 4.0 , 5.1 to 25.6 and 13.0 to $21.9 \mu \mathrm{M}$, respectively (Table 1 ). In experiments on $26 \mathrm{May}$ and in July, August and September 1997, when ambient levels of $\mathrm{NH}_{4}{ }^{+}$and $\mathrm{NO}_{3}{ }^{-}$had dropped to $<0.9$ and $<2.5 \mu \mathrm{M}$ respectively, we again observed increases of $\mathrm{NH}_{4}{ }^{+}$concentrations during the incubation period. In the September 1997 experiments, DON concentrations in unsupplemented lake water were also measured at the start $(27.6 \mu \mathrm{M})$ and end (15.1 $\mu \mathrm{M})$ of the incubation. This decrease corresponded to about 2.5 times the measured increase in $\mathrm{NH}_{4}{ }^{+}\left(4.7 \mu \mathrm{M}_{i}\right.$ Fig. 1E), presumably the remainder of the DON had been transformed to particulate organic $\mathrm{N}$ in the form of bacterial cells. (The increase in urea concentration in this experiment was $<0.5 \mu \mathrm{M} N$.)

The effect of adding the nitrification inhibitors to these samples was not consistent. The response to $\mathrm{N}$ serve shown in the experiment begun on 26 August 1996 (Fig. 1B) suggested that rapid nitrification was occurring which masked the release of $\mathrm{NH}_{4}{ }^{+}$in the control sample. However, in the following experiment (Fig. 1C) the addition of $\mathrm{N}$-serve had no apparent effect on the pattern of $\mathrm{NH}_{4}{ }^{+}$concentration increase. Subsequently, in 3 other experiments (January, May and July 1997) the addition of $\mathrm{N}$-serve, picollinic acid, thiourea or allyl-thiourea to Kinneret water did not affect changes of $\mathrm{NH}_{4}{ }^{+}$concentrations observed during the incubation period (data not shown). In contrast, cyanoguanidine, reported to be a very effective inhibitor of nitrification (Guiraud et al. 1989), appeared to enhance the accumulation of $\mathrm{NH}_{4}{ }^{+}$on 10 August 1997 (Fig. 1D) and in September 1997 (Fig. 1E).

It is noteworthy that the experiment in August 1997 was the only occasion when $>2 \mu \mathrm{M} N$ urea appeared to be released from the ambient DON in the lake water. (Table 1, Fig. 1F). With the exception of 10 August 1997, ambient concentrations of urea measured in lake water were not greater than $1 \mu \mathrm{M} \mathrm{N}$ (Table 1). Note, however, that we did not check urea concentrations either in the lake or in experiments prior to January 1997.

In contrast to Lake Kinneret, we could not trace any release of $\mathrm{NH}_{4}{ }^{+}$or urea from the ambient DON of Charente estuarine water. Here we found that the initial concentrations of $\mathrm{NH}_{4}{ }^{+}(4$ to $5 \mu \mathrm{M}$ ) and urea (1 to $1.5 \mu \mathrm{M} N$ ) dropped to undetectable levels within 1 to $3 d$, presumably as a result of microbial uptake. No consistent effect was found on the changes in concentrations of $\mathrm{NH}_{4}{ }^{+}$with the addition of cyanoguanidine. No changes during the incubation were detected in the concentrations of $\mathrm{NO}_{3}{ }^{-}$or DON (30 to 34 and 40 to $45 \mu \mathrm{M}$, respectively) which were much higher than in lake water. However, in a single experiment with

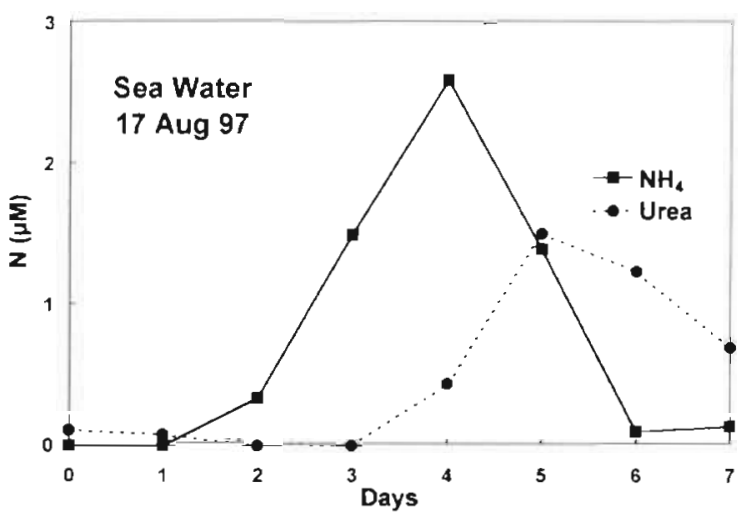

Fig. 2. Changes in concentrations of $\mathrm{NH}_{4}{ }^{+}(\mu \mathrm{M})$ and urea $(\mu \mathrm{M}$ $\mathrm{N})$ during incubation of sea water sampled near lle de Ré prefiltered through $1 \mu \mathrm{m}$ pore polycarbonate membranes

coastal waters (ambient concentrations of $\mathrm{NH}_{4}{ }^{+}$: $0.11 \mu_{\mathrm{i}} \mathrm{NO}_{2}{ }^{-}+\mathrm{NO}_{3}{ }^{-}: 0.93 \mu \mathrm{M}$; and DON: $2.64 \mu \mathrm{M}$ ) we observed an apparent release of $\mathrm{NH}_{4}$ during the first $4 \mathrm{~d}$ of incubation followed by a rapid decrease (Fig. 2). In this case, there was also an increase of urea concentrations after the third day of incubation.

\section{Release of $\mathrm{NH}_{4}{ }^{+}$and urea from added DON sources}

In addition to determining $\mathrm{NH}_{4}{ }^{+}$release from the ambient DON, we evaluated the potential of the native bacterial populations or enzymes free in solution to release $\mathrm{NH}_{4}^{+}$or urea from a variety of DON compounds added to lake, estuarine or coastal water. In the case of Lake Kinneret water, we found that $\mathrm{NH}_{4}{ }^{+}$was released from most organic $N$ compounds (guanine,

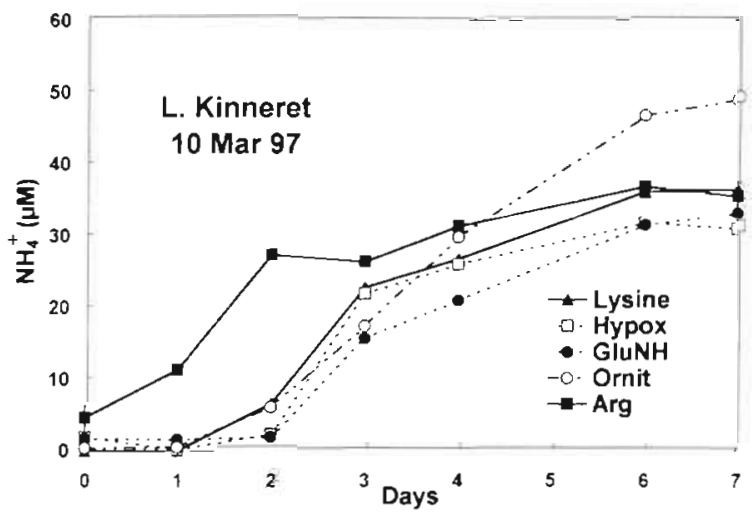

Fig. 3. Changes in concentration of $\mathrm{NH}_{4}{ }^{*}(\mu \mathrm{M})$ during incubation of lake water prefiltered through $1 \mu \mathrm{m}$ pore polycarbonate membranes and supplemented with organic nitrogen compounds (lysine, hypoxanthine, glucosamine, ornithine or arginine) as indicated 
hypoxanthine, ornithine, arginine, lysine, and glucosamine) tested in all experiments from August 1996 through September 1997 (Fig. 3). Additions of thymine and adenine ( 1 experiment only) did not give rise to an obvious release of $\mathrm{NH}_{4}{ }^{+}$(data not shown). Moreover, with hypoxanthine and guanine (Fig. 4A) and with arginine (Fig. 4B) but not with other DON supplements, we also consistently observed substantial increases in urea concentrations during the incubation period.

Although $\mathrm{NH}_{4}{ }^{+}$release was also observed when glucosamine, arginine or thymine was added to Charente water, this was not the case with hypoxanthine and guanine (Fig. 5A). Instead, with these 2 latter substrates, we found a rise in urea concentration (Fig. 5B). Glucosamine, arginine and, to a lesser extent, thymine also gave rise to urea in addition to $\mathrm{NH}_{4}{ }^{+}$in these samples (Fig. 5B).

We observed increases in concentrations of $\mathrm{NH}_{4}{ }^{+}$ when coastal sea water was supplemented with arginine, glucosamine, guanine, hypoxanthine and, to a lesser extent, leucine and thymine. Here too, increases
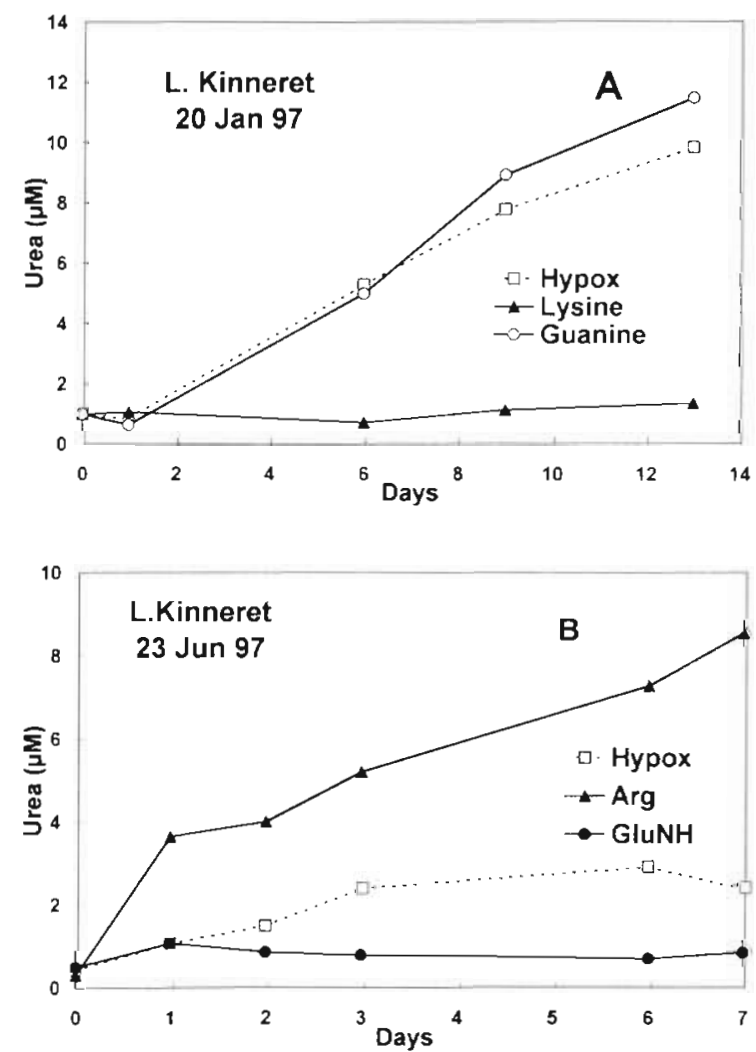

Fig. 4. Changes in concentration of urea $(\mu \mathrm{MN})$ during incubation of lake water prefiltered through $1 \mu \mathrm{m}$ pore polycarbonate membranes and supplemented with organic nitrogen compounds: (A) hypoxanthine, lysine or guanine; (B) hypoxanthine, arginine or glucosamine of urea concentrations were observed with additions of hypoxanthine and guanine and, in a very erratic manner, with arginine and thymine (Fig. 6)
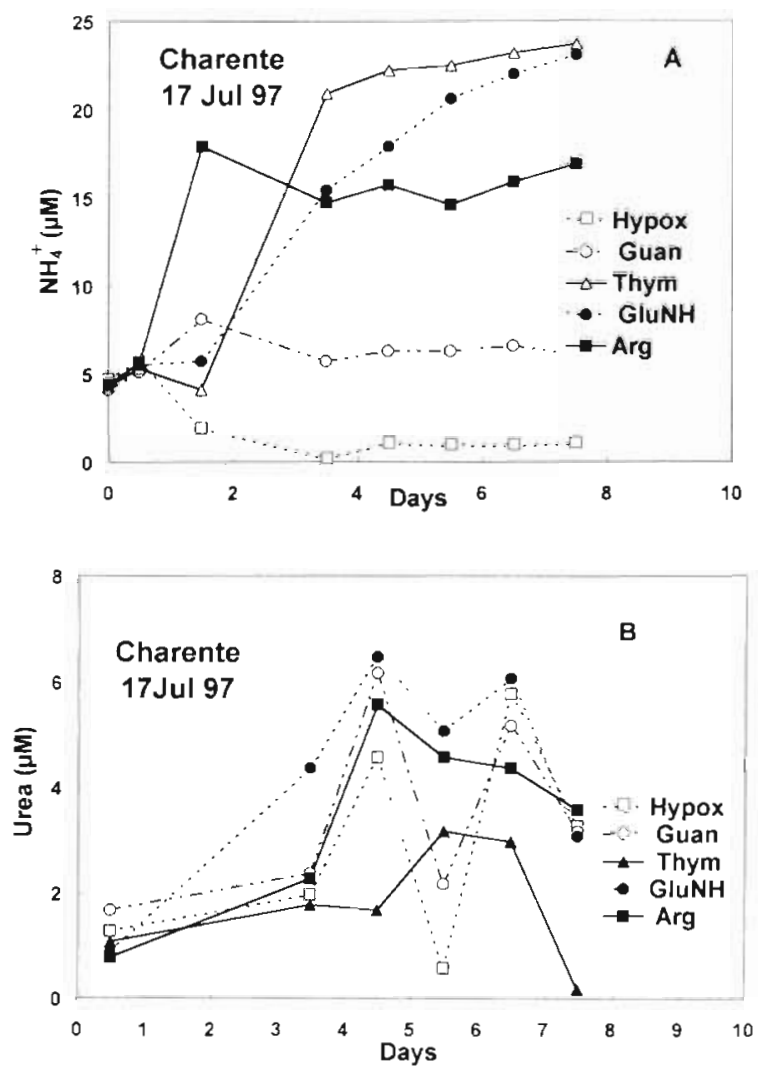

Fig. 5. Changes in concentration of (A) $\mathrm{NH}_{4}^{-}(\mu \mathrm{M})$ and (B) urea $(\mu \mathrm{M} N)$ during incubation of Charente estuarine water prefiltered through $1 \mu \mathrm{m}$ pore polycarbonate membranes and supplemented with hypoxanthine, guanine, thymine, glucosamine or arginine

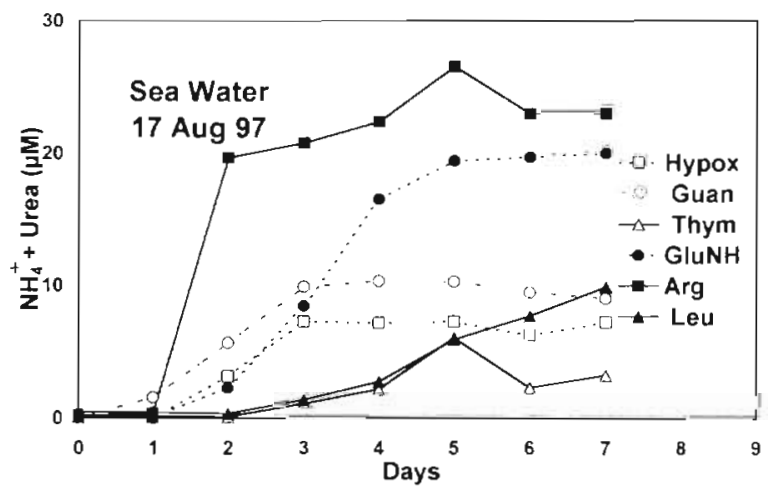

Fig. 6. Changes in concentration of $\mathrm{NH}_{4}{ }^{+}$plus urea $(\mu \mathrm{MN})$ during incubation of sea water sampled near lle de Ré, prefiltered through $1 \mu \mathrm{m}$ pore polycarbonate membranes supplemented with hypoxanthine, guanine, thymine, glucosamine, arginine or leucine 


\section{DISCUSSION}

Despite considerable variability, the results of these experiments clearly indicate the potential for degradation of DON to $\mathrm{NH}_{4}{ }^{+}$in natural waters by indigenous bacteria and/or free dissolved enzymes. Furthermore, these experiments confirm the suggestion that the transformations of some compounds likely to occur in the DON pool, such as guanine, hypoxanthine, arginine (Antia et al 1991) and perhaps glucosamine, can give rise to urea which in turn can be effectively exploited by the ambient microbiota. The results shown here support the idea that the breakdown of DON with the concomitant release of readily available compounds such as $\mathrm{NH}_{4}{ }^{+}$or urea could be an important process in $\mathrm{N}$ nutrition of phytoplankton and bacteria (Berman 1997).

We attempted to eliminate some of the complications which might have been caused by algal uptake and recycling of $\mathrm{NH}_{4}{ }^{+}$or urea by pre-filtering the water samples through 1 or $1.2 \mu \mathrm{m}$ pore filters. Obviously, not only the direct processes of breakdown of the initially present (or added) DON substrates to $\mathrm{NH}_{4}{ }^{+}$and/or urea were occurring in the experimental flasks but, at the same time, uptake and recycling of $\mathrm{N}$ compounds by the ambient bacteria were also taking place. Thus, the rises in concentrations of $\mathrm{NH}_{4}^{*}$ or urea which were recorded at any given time during these experiments represented the net release of these compounds from the DON pool; total release may have been considerably greater.

The addition of guanine, hypoxanthine and arginine to filtered lake and coastal sea water not only gave rise to $\mathrm{NH}_{4}{ }^{+}$but also to significant concentrations of urea. The catabolism of purines may generate either $\mathrm{NH}_{4}{ }^{+}$ or, alternately, urea and ornithine, but both enzymatic pathways have not been observed within single organisms (Antia et al. 1991). Presumably, the appearance of both $\mathrm{NH}_{4}{ }^{+}$and urea when guanine or hypoxanthine were added to Lake Kinneret or coastal water samples was due to the presence within the bacterial assemblage of separate groups of organisms having the metabolic capability to generate both these compounds, whereas in the Charente estuary microorganisms with the urea-ornithine pathway predominated. The release of urea from purines, which may enter the DON pool as breakdown products from nucleic acids, could explain, at least partially, the origin of significant urea concentrations sometimes reported in freshwater lakes (Berman 1974, Mitamura \& Saijo 1981). Purines and their derivatives may also be a source for urea in the marine environment (Antia et al. 1991).

Surprisingly, when glucosamine was added to Charente water, both $\mathrm{NH}_{4}^{+}$and urea concentrations increased during the incubation: this did not occur in the experiments with Lake Kinneret or coastal water. As there is no obvious direct biochemical pathway from glucosamine to urea, at present we have no explanation for this observation.

The effect of nitrification inhibitors was variable. In some (e.g. Fig. 1B,D,E), but not all (Fig 1C), cases, the increases of observed $\mathrm{NH}_{4}{ }^{+}$concentrations in samples with added inhibitor relative to those without inhibitor suggested that there was some $\mathrm{NH}_{4}{ }^{+}$flux to $\mathrm{NO}_{3}{ }^{-}$ occurring in the unsupplemented samples. The sharp changes in the slope of $\mathrm{NH}_{4}{ }^{+}$concentrations with time shown in Fig. 1D,E may also reflect the potential for nitrification and suggest that this process occurred when sufficiently high concentrations of $\mathrm{NH}_{4}{ }^{+}$and an active population of nitrifying bacteria accumulated in the experimental flasks. In one experiment (Fig. 1F) the addition of cyanoguanidine may have also led to a slight increase of accumulation of urea. The observed increases in $\mathrm{NH}_{4}{ }^{+}$when the inhibitors were added did not derive from breakdown of these compounds because previously we found that addition of cyanoguanidine or $\mathrm{N}$-serve to pre-filtered Kinneret water did not lead to any accumulation of $\mathrm{NH}_{4}{ }^{+}$during the incubations.

It is impossible to estimate realistic rates for the liberation of $\mathrm{NH}_{4}{ }^{+}$or urea from the DON pool in nature from these experiments because of the complications caused by the presence of bacteria that could rapidly exploit these $\mathrm{N}$ sources for growth. In many natural waters (for example, large areas of oceanic near-surface waters, or the epilimnion of Lake Kinneret in summer-fall) it seems reasonable to assume that there is a constant flux of $\mathrm{NH}_{4}{ }^{+}$and/or urea from suitable DON pool components to phytoplankton and bacteria (Berman 1997), especially when ambient levels of $\mathrm{NH}_{4}{ }^{+}$or $\mathrm{NO}_{3}{ }^{-}$are low. Although this flux has usually not been observed directly (presumably because of the fast uptake of $\mathrm{NH}_{4}{ }^{+}$and/or urea by the ambient microorganisms) and although quantitative data are as yet unavailable, we suggest that the DON to $\mathrm{NH}_{4}{ }^{+}$and urea pathway could be extremely significant for the $\mathrm{N}$ nutrition of aquatic microbiota in waters with low ambient levels of $\mathrm{NO}_{3}{ }^{-}$or $\mathrm{NH}_{4}{ }^{+}$. For example, it is possible that, over large oceanic areas with low ambient. levels of DIN, nitrogen available to other microplankton can be derived from DON released from Trichodesmium that fixes dissolved $\mathrm{N}_{2}$ (Karl et al. 1997).

A priori, it would seem reasonable to conclude that the major pathway of $\mathrm{N}$ recycling from the DON pool in nature would be by the process examined in this paper, i.e. through the bacterial or free enzyme mediated breakdown of indigenous DON compounds to easily exploitable sources such as $\mathrm{NH}_{4}{ }^{+}$or urea, rather than by direct phytoplankton uptake of organic nitrogen. Nevertheless, the capability of some algal species 
to directly exploit DON substrates suggests that this capacity gives these organisms some specific ecological benefit. In this connection, it is intriguing to note the suggestion that dissolved organic compounds originating from land drainage favoured the growth of potentially toxic flagellates over that of harmless algal species (Paerl 1988). In particular, humic acids, such as are frequently leached from forested areas, appeared to promote the growth of dinoflagellates (including toxic species) preferentially to diatoms and other algae (Granéli \& Moreira 1990). Subsequently, Carlsson \& Granéli (1993) and Carlsson et al. (1993) showed that both bacterial degradation of humic compounds and algal growth can be sustained by humic-bound nitrogen. These authors suggested that a plausible mechanism of nitrogen supply to phytoplankton could be via organic $\mathrm{N}$ assimilation by bacteria which are then grazed by micropredators that excrete ammonium. The released ammonium is then taken up by autotrophic algae. In this scheme, the activity of several components of the microbial loop results in making nitrogen bound in allocthonous DON available to phytoplankton. However, the direct release of available $\mathrm{N}$ from DON by microbial enzymatic activity was not investigated in these studies.

Much still remains to be clarified about the role of DON in natural waters. Nevertheless, it seems reasonable to postulate that, both in marine and freshwaters, some components of the aquatic DON pool undergo rapid chemical transformations and thereby serve as important sources of readily available $\mathrm{N}$ for aquatic microorganisms. As noted, our present results do not give any quantitative estimate of the kinetics of the degradation of DON pool compounds to $\mathrm{NH}_{4}{ }^{+}$and urea in nature. Hence, the development of techniques to measure the extent of this nitrogen flux in various aquatic environments presents a research challenge for the future.

Acknowledgements. We are grateful to 3 conscientious reviewers whose comments helped to improve this paper considerably. We thank Fatima Achame and Françoise Mornet (France) and S. Chava, B. Kaplan and Y. Viner (Israel) for technical help. This study was partially funded by a grant from the Office of the Israel Water Commissioner, and by the 'Région Poitou-Charentes', France. A contribution of Israel Oceanographic and Limnological Research.

\section{LITERATURE CITED}

Anonymous (1992) Standard methods for the examination of water and wastewater, 19th edn. American Public Health Association, Washington, DC

Antia NJ, Berland BR, Bonin DJ (1980) Proposal for an abridged nitrogen turnover cycle in certain marine planktonic systems involving hypoxanthine-guanine excretion by ciliates and their reutilization by phytoplankton. Mar Ecol Prog Ser 2:97-103
Antia NJ, Berland BR, Bonin DJ, Maestrini SY (1975) Comparative evaluation of certain organic and inorganic sources of nitrogen for phototrophic growth of marine microalgae. J Mar Biol Assoc UK 55:519-539

Antia NJ, Harrison PJ, Oliveira L (1991) The role of dissolved organic nitrogen in phytoplankton nutrition, cell biology and ecology. Phycologia 30:1-89

Berg GM, Glibert PM, Lomas MW, Burford M (1997) Organic nitrogen uptake and growth by the chrysophyte Aureococcus anophagefferens during a brown tide event. Mar Biol 129:377-387

Berman T (1974) Urea in the waters of Lake Kinneret (Sea of Galilee). Limnol Oceanogr 19:437-440

Berman T (1997) Dissolved organic nitrogen utilization by an Aphanizomenon bloom in. Lake Kinneret. J Plankton Res 19:577-586

Berman T, Chava S, Kaplan B, Wynne D (1991) Dissolved organic substrates as phosphorus and nitrogen sources for axenic batch cultures of freshwater green algae. Phycologia 30:339-345

Bronk DA, Glibert PM, Ward BB (1994) Nitrogen uptake, dissolved organic nitrogen release, and new production. Science 265:1843-1846

Carlsson P, Granéli E (1993) Availability of humic bound nitrogen for coastal phytoplankton. Estuar Coast Shelf Sci 36:433-447

Carlsson P, Zuleika Segatto A, Granéli E (1993) Nitrogen bound to humic matter of terrestrial origin - a nitrogen pool for coastal phytoplankton? Mar Ecol Prog Ser 97:105-116

Flynn KJ, Butler 1 (1986) Nitrogen sources for the growth of marine microalgae: role of dissolved free amino acids. Mar Ecol Prog Ser 34:281-304

Glibert PM, Garside C, Fuhrman JA, Roman MR (1991) Timedependent coupling of inorganic and organic nitrogen uptake and regeneration in the plume of the Chesapeake Bay estuary and its regulation by large: heterotrophs. Limnol Oceanogr 36:895-909

Granéli E, Edler L, Gedziorowska D, Nyman U (1985) Influence of humic and fulvic acids on Prorocentrum minimum (Pav.) J. Schiller. In: Anderson DM, White AW, Baden DG (eds) Proceedings of the third international conference on Toxic Dinoflagellates, St Andrews, NB, Canada, June 8-12, 1985. Elsevier Sci Publ, New York, p 201-206

Granéli E, Moreíra MO (1990) Effects of river water of different origin on the growth of marine dinoflagellates and diatoms in laboratory cultures. J Exp Mar Biol Ecol 136: $89-106$

Guiraud G, Marol C. Thibaud MG (1989) Mineralisation of nitrogen in the presence of a nitrification inhibitor. Soil Biol Biochem 21(1):29-34

Jackson GA, Williams PM (1985) Importance of dissolved organic nitrogen and phosphorus to biological nutrient cycling. Deep-Sea Res 32:223-235

Kapp R, Stevens SE Jr, Fox JL (1975) A survey of available nitrogen sources for the growth of the blue-green alga, Agmenellum quadruplicatum. Arch Microbiol 104:135-138

Karl D, Letelier R, Tupas L, Dore J, Christian J, Hebel D (1997) The role of nitrogen fixation in biogeochemical cycling in the subtropical North Pacific Ocean. Nature 388:533-538

Libby PS, Wheeler PA (1997) Particulate and dissolved organic nitrogen in the central and eastern Equatorial Pacific. Deep-Sea Res 44:345-361

McCarthy JJ (1970) A urease method for urea in seawater Limnol Oceanogr 15:303-313

McCarthy JJ (1972) The uptake of urea by natural populations of marine phytoplankton. Limnol Oceanogr 17 $738-748$ 
Mitamura O, Saijo Y (1981) Studies on the seasonal changes of dissolved organic carbon, nitrogen, phosphorus and urea concentrations in Lake Biwa. Arch Hydrobiol 91: $1-14$

Neilson. AH, Larsson $\mathrm{T}$ (1980) The utilisation of organic nitrogen for growth of algae: physiological aspects. Physiol Plant 48:542-553

Nydahl (1978) On the peroxodisulphate oxidation of total nitrogen in waters to nitrate. Water Res 12:1123-1130

Ogata T, Koike K, Nomura S, Kodama M (1996) Utilization of organic substances for growth and toxin production by Alexandrium tamarense. In: Yasumoto $T$, Oshima $Y$, Fukuyo Y (eds) Harmful and toxic algal blooms. Intergovernmental Oceanographic Commission of UNESCO, Paris, p 343-346

Oliveira L, Huynh H (1990) Phototrophic growth of microalgae with allantoic acid or hypoxanthine serving as nitrogen source, implications for purine- $N$ utilization. Can J Fish Aquat Sci 47:351-356

Paerl HW (1988) Nuisance phytoplankton blooms in coastal estuarine, and inland waters. Limnol Oceanogr 33 823-847

Palenik B, Kieber DJ, Morel FMM (1988/1989) Dissolved organic nitrogen use by phytoplankton: the role of cellsurface enzymes. Biol Oceanogr 6:347-354

Editorial responsibility: Patricia Glibert,

Cambridge, Maryland, USA
Pantoja S, Lee C, Marecek JF (1997) Hydrolysis of peptides in seawater and sediment. Mar Chem 57:25-40

Paul JH, Deflaun MF, Jeffrey WH (1988) Mechanisms of DNA utilization by estuarine microbial populations. Appl Environ Microbiol 54:1682-1688

Price NM, Harrison PJ (1988) Uptake of urea C and urea N by the coastal marine diatom Thalassiosira pseudonana. Limnol Oceanogr 33:528-537

Richards L, Thurston CF (1980) Uptake of leucine and tyrosine and their intracellular pools in Chlorella fusca var. vacuolata. J Gen Microbiol 121:39-47

Simon M, Rosenstock B (1992) Carbon and nitrogen sources of planktonic bacteria in Lake Constance studied by the composition and isotope dilution of intracellular amino acids. Limnol Oceanogr 37:1496-1511

Solarzano L (1969) Determination of ammonia in natural waters by the phenol-hypochlorite method. Limnol Oceanogr 14:799-801

Tamminen T, Irmisch A (1.996) Urea uptake kinetics of a midsummer planktonic community on the SW coast of Finland. Mar Ecol Prog Ser 130:201-211

Turner MF (1979) Nutrition of some marine microalgae with special reference to vitamin requirements and utilization of nitrogen and carbon sources. J Mar Biol Assoc UK 59: $535-552$

Submitted: November 20, 1997; Accepted: May 5, 1998 Proofs received from author(s): December 9, 1998 